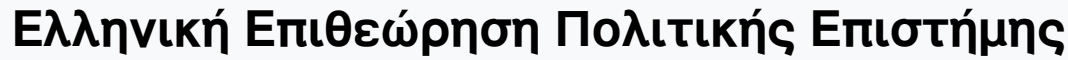

Tó. 45, Ap. 1 (2019)

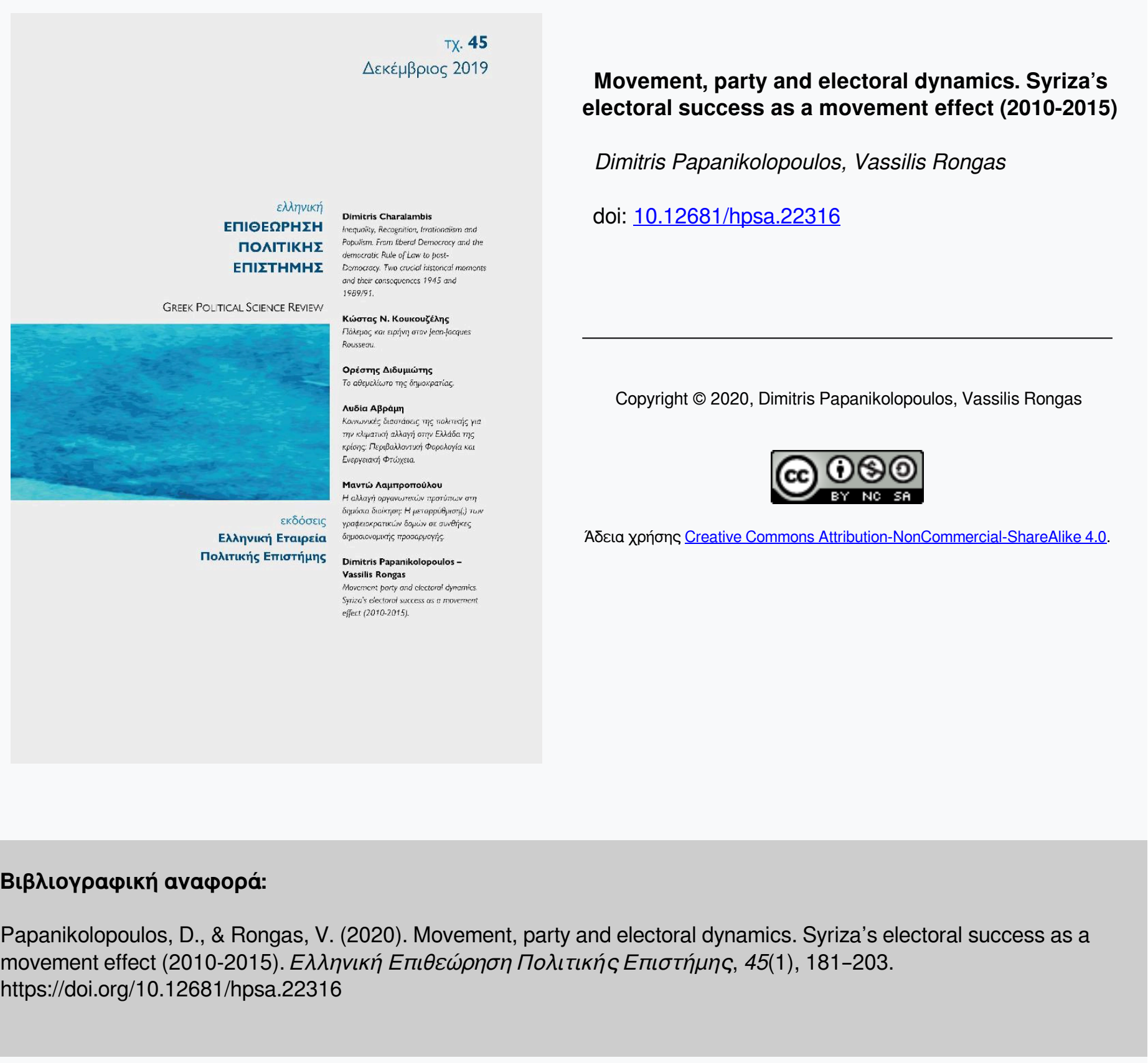




\title{
Movement, party and electoral dynamics. Syriza's electoral success as a movement effect (2010-2015)
}

\section{Dimitris Papanikolopoulos*, Vassilis Rongas**}

\begin{abstract}
In this article we approach SYRIZA's electoral success between 2012 and 2015 as a movement effect. We focus on SYRIZA's features, strategy and message that have been developed on the grounds of its movement activity, as well as on the external political conditions which SYRIZA seems to take advantage of. We argue that the anti-austerity campaign created the necessary preconditions for the electoral and political rise of SYRIZA, namely the emergence of a new political boundary between pro- and antiMemorandum forces and a subsequent majoritarian socio-political category that could be transformed into a privileged electoral pool for SYRIZA.
\end{abstract}

\section{Keywords}

SYRIZA, protest, anti-austerity, political parties, Greece

* Dr of Political Sciences, Panteion University, Independent researcher, @ papanik8@yahoo.com

** PhD candidate in the Department of Sociology, University of Crete, @ eomer 7@yahoo.com 


\section{INTRODUCTION}

SYRIZA was the winner of $25^{\text {th }}$ January 2015 elections obtaining more than $36 \%$ and securing the first place in the polls. The electoral result allowed SYRIZA to form a coalition government along with ANEL, a rightist party which had secured less than $5 \%$. SYRIZA had seen its percentages rising from 4.5\% in 2009 elections to 17\% in May 2012 elections and $27 \%$ a month after. How these results became possible? It must be considered only as a product of the economic crisis, on the one hand, and of Alexis Tsipras' leadership and strategy, on the other (Moschonas 2013: 36)?

Electoral consequences of this type indeed must be attributed, according to Hernandez and Kriesi, as a by-product of financial and economic crisis in Europe. More precisely, the two authors argue that 1 ) the more hit is a country by the crisis, 2) the less economic hardship it has experienced in the recent past, 3) the more dramatic the unfolding key events are, the more is this country likely to see its ruling parties punished by economic voting, especially in the second post-crisis elections (Hernandez and Kriesi, 2016). Hernandez and Kriesi combine the economic voting explanation with a party system restructuring explanation which relies upon the idea that the great recession may accentuate long term trends of system change, destabilizing further party systems in Europe in the detriment of mainstream ruling parties and on behalf of radical populist right or left parties. Undoubtedly Greece witnessed all the aforementioned developments. On the other hand, the extent of changes raises a new question: why SYRIZA, a leftist minor party (and not another party on the left or on the right side of the political spectrum) managed to reach governmental power (instead of seeing its percentages simply rise)?

A partial answer can probably be drawn from the distinction that Mair (Mair, 2011) introduced according to which political parties are divided in mainstream parties who fulfill the task of responsible government and peripheral parties who fulfill the task of popular representation and give voice to challengers. This division of labor gives shape to long term dealignment/realignment processes due to changing social conflicts. In this context Kriesi argues that, «the Great Recession may constitute a 'critical juncture' that accelerates and/or reshapes such realignment processes in the party system giving rise to extraordinary punishments to mainstream incumbents which may turn out to be irreversible in the medium term» (Kriesi, 2015a:25-26). SYRIZA was a peripheral party that through providing access to popular challengers and social movements within the party system managed to gain political leverage. However, SYRIZA's electoral success has rather to do with challenging the division of labor between parties than trying to take advantage of it. «The call to take governmental power, based on the unity of the entire left [...] became an inspiring response to the widespread disenchantment of the population with the long-standing bipartisan political system» (Spourdalakis, 2014:359). This call was a 
part of a distinct strategy with three pillars: the «active participation in the social field», the «complete and unreserved presence in the institutions of social and political representation» and the «development of a program» (Spourdalakis, 2014:358). This strategy, which has been characterized (Eleytheriou, Spourdalakis and Tsakiris, 2013) as an «against and beyond» strategy in comparison with the Communist Party (KKE)'s movement vanguardism and the moderate Democratic Left (DIMAR)'s governmentalism leads us to the field of movement activity.

It is true that only recently social movement scholars started to examine more systematically the interactions between social movements and party politics (Almeida, 2010; Kriesi, 2015b; Hutter, Kriesi and Lorenzini, forthcoming), political cleavages (Hutter, 2014) or elections (Mc Adam and Tarrow 2010, 2013). Some Greek scholars have already indicated the positive relation between protests and a new political cleavage (Aslanidis and Marantzidis, 2016), a new electoral regime (Serdedakis and Koufidi, forthcoming) or the rise of SYRIZA (Simiti, 2014; Karyotis and Rudig, 2017; Vogiatzoglou, 2017). In contrast, Oikonomakis disagrees with the latter, arguing that there is no relation between «the movement of the squares» and the rise of SYRIZA, given the widespread crisis of political representation and critics on the institutions (parties included). He claims that people protesting for many years turned once again to the electoral arena, not because they trusted parties and the institutional procedures, but because «the movement of the squares» failed to create alternative structures (Oikonomakis, 2017). However, this argumentation does not take into account that the majority of Greek Indignados was protesting against austerity rather than claiming for direct/real democracy. Only left-wing youth and antiauthoritarian/anarchist groups were really interested in prefigurative politics and willing to engage in a long-lasting and/or costly activity that would bring such an outcome. In contrast, the majority of participants, especially the elders, joined only the most important protests and defected rapidly when they failed to stop Parliament's ballot on Mid-term austerity program (Oikonomakis, 2017).

Part of the literature of social movements shows that, as Goldstone stresses it, «there is only a fuzzy and permeable boundary between institutionalized and non-institutionalized politics» (Goldstone, 2003:13). It is always crucial to think «electoral choices and protest, mobilization by political parties and social movements" as parts of "the same process of political interest intermediation» (Kriesi, 2015c:67). In this context, electoral, protest and economic cycles are interrelated and quite often overlapping. Of course, it seems that «ordinarily, defiance is first expressed in the voting booth simply because, whether defiant or not, people have been socialized within a political culture that defines voting as the mechanism through which political change can and should properly occur» (Piven \& Cloward, 1977: 15). 
According to Karyotis and Rudig's research, «over 54\% of those who demonstrated against austerity between 2010 and 2015 voted for SYRIZA in the January 2015 elections» (Karyotis and Rudig, 2017:8). We believe that the external political conditions which SYRIZA seems to take advantage of were the immediate results of an intensive movement campaign, while both the party's political strategy and particular ideological and organizational features are developed on the grounds of its movement activity. Consequently, we approach the spectacular rise of SYRIZA as a movement effect and not as a populist phenomenon, while we address the issue whether its electoral success contributed to the decline of mass mobilization.

\section{THE ANTI-MEMORANDUM MOVEMENT CAMPAIGN AND THE EMERGENCE OF A NEW POLITICAL CLEAVAGE}

As Kriesi notes, «voters resort to the protest arena to the extent that they are unable to express themselves in the electoral or direct democratic channel or that their vote has no impact» or simply «because the next elections are too far off» (Kriesi, 2015c: 68-69). This theoretical insight applies perfectly to the Greek case. Let's have a look at the core data. In 2009 ruling New Democracy lost the snap elections on the grounds of the announcement of austerity measures by Prime Minister Kostas Karamanlis. PASOK secured an easy victory, but the new Prime Minister Papandreou facing an ongoing public deficit and sovereign debt was led to sign the first bailout package with troika in 2010 in exchange of unprecedented austerity measures. This decision triggered discontent among Greeks, while it would be difficult for new elections to take place soon. Greek citizens chose to protest, according to Kriesi's point of view. Pursuant to our hypothesis, the unprecedented anti-austerity campaign that followed not only had important impacts on institutional and party level (Kousis, 2013; Kousis and Kanellopoulos, 2014) but, furthermore, gave shape both to the electoral cycle and its outcomes.

More specifically, the massive political dealignment/realignment process Greece witnessed firstly in 2012 double elections (Voulgaris and Nikolakopoulos, 2014) and finally in 2015 elections that brought SYRIZA to power cannot be explained without taking into account a series of causal mechanisms occurred basically in the social movement level. Protest cycle that opened up in spring 2010 was marked by intensive conflict and its geographical and sectoral diffusion (Psimitis, 2011), since tens of large protest events with high number of participants and high number of parallel/synchronized events took place across the country (Kousis and Kanellopoulos, 2014). In the course of this movement campaign a broad anti-austerity coalition including at least 5 distinct networks (trade unions, SYRIZA's organizations, KKE and its frontal organizations, ANTARSYA's network, 
anarchist groups) was formed (Kanellopoulos et al, 2017). Traditional boundaries between these distinct networks lost salience on behalf of a new political cleavage: antimemorandum vs pro-memorandum forces (Papanikolopoulos et al, 2014).

This boundary change (McAdam et al, 2001) resulted from the increasing polarization between the ruling mainstream parties on the one hand and a wide range of hard-hit social groups along with the (mostly left wing and trade unions) political opposition on the other. Political climate was so polarized that pro-memorandum forces resorted to open propaganda (Doxiades, 2016) and repression. This strategy triggered a «backlash effect» deepening even more the new cleavage. Competition across the lines was combined with convergence (McAdam et al, 2001) among different components of every single bloc. Convergence between previously political opponents was based on the exposition in common threats, on the coexistence in the same protest events as well as on a more or less common framing (Papanikolopoulos et al, 2014). For years brokers acted in order to connect previously unconnected individuals and groups, while common diagnostic and prognostic frames (Benford and Snow, 2000) tended to get formed via a «bridging» process (Snow, Rochford, Worden and Benford, 1986) between a left-wing framing and a patriotic one. This inclusive message became a winning discursive formula widely and rapidly diffused. Figure 1, which presents an explanatory schema McAdam, Tarrow and Tilly (2001:323) introduced in order to explain polarization, depicts the complex process through which the «anti-memorandum» socio-political category emerged.

Without the formation of this new majoritarian socio-political category that could be transformed (at least in part) in a massive electoral pool for SYRIZA, the spectacular rise of the latter seems impossible. «Social categorization» process may prevent somebody from get exposed to an active minority's influence, if he/she believes they don't share the same category (Papastamou and Prodromitis, 2016:108). Consequently, SYRIZA's perception as part of an inclusive category wider than the traditional political ones was a critical step. In that sense, perceiving anti-memorandum campaign as an opening of the «structure of political opportunities» (Eleftheriou et al, 2013:7) for new political outcomes seems to us an important assumption. Especially Greek Indignados protests facilitated voter defection from the traditional two-party system, strongly delegitimizing governmental parties and legitimizing participating anti-memorandum political forces (Eleftheriou, 2015). Deactivation of boundaries and convergence between previously oppositional forces as well as the creation of a new boundary between them and the probailout socio-political bloc resulted to the emergence of a social category and a new political cleavage, yet not to a major new actor. Movements, as Castells puts it, «can hardly be co-opted by political parties (which are universally distrusted), although political parties may profit from the change of mind provoked by the movement in the public opinion. [...] 
they can also be public opinion movements, with electoral consequences Castells, 2012:227). It seems that this is the case under examination.

\section{Figure 1: Polarization process}

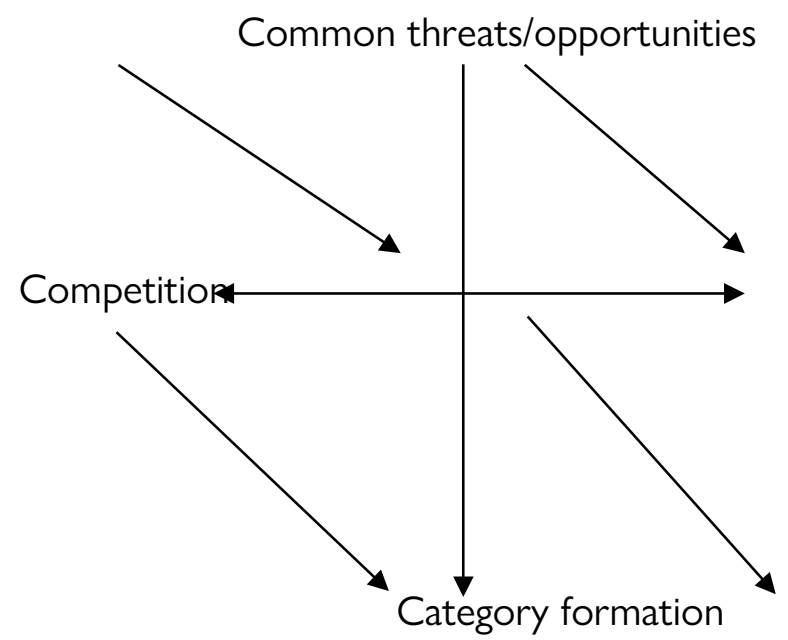

Brokerage/Diffusion

McAdam and Tilly 2001:323

\section{SYRIZA BETWEEN CONTENTION AND CONVENTION}

From the beginning of the previous decade SYRIZA and KKE decided to turn to social movements in order to increase their political leverage (Tsakatika and Eleftheriou, 2013). Thus, they increased human, technical, economic and, of course, political resources that traditionally provided social movements. Parties of the Left in Greece were historically something more than institutional allies of social movements: they were their main carriers (Papanikolopoulos 2015b, 2016). SYRIZA's and KKE's decision to actively participate in the popular anti-austerity campaign, apart from confirming that «left is more likely to rely on public protest outside of the party system than the right» (Kriesi, 2015b:672), transformed the two leftist parties into parliamentary spokesmen of the anti-austerity movement forces.

According to Giugni and Lorenzini's assumption «contentious reactions to economic crises are more likely when oppositional parties succeed in framing the crisis in terms of specific responsibilities of the government»(Giugni and Lorenzini, 2015:24). True, from the beginning of crisis it was predominantly parties of the Left (SYRIZA and KKE) who blamed Greek government for its performance in crisis management (Sommer et al, 2016). Movement actors engaged in the same blame game (Kanellopoulos et al, 2015). As Kanellopoulos et al's research indicates parties of the Left, left-wing social movement organizations and trade unions were sharing both diagnostic and prognostic frames in a crucial degree (Kanellopoulos et al, 2014). In other words, oppositional forces were December 2019, vol. 45 
speaking with one voice from the very beginning and their common narrative was drawn from an ideological compatibility. In this context, the hypothesis, according to which SYRIZA adopted unilaterally the discourse of protesters (Karyotis and Rudig, 2017:8; Prentoulis and Thomassen, 2014:227; Aslanidis and Marantzidis, 2016:149) is not valid. In contrast, SYRIZA contributed actively in the formation of the anti-memorandum discursive formula, due to its theoretical and practical elaborations and the expertise of its economists and other academic party members, as well as by the articulation of parliamentary, trade unions and protest oppositional narrative.

However, SYRIZA and KKE did not adopt the same option of «social movement partyism» (Almeida, 2010). Contrary to KKE's movement vanguardism", SYRIZA combined movement to governmental concerns ${ }^{2}$ (Eleftheriou, Spourdalakis and Tsakiris, 2013). Furthermore, SYRIZA's (and especially its Youth branch) unreserved presence in almost all protest events along with its decision to avoid patronizing spontaneity and innovations of the movements (Spourdalakis, 2014:358) ${ }^{3}$, offered it a «degree centrality» (Krinsky and Crossley, 2014: 12) in the sense that it had not a key-connecting role (a «betweeness centrality»), but disposed many connections to others, inclusive framing, and position in the overlapping area between moderates and radicals (Kanellopoulos et al, 2017:110) ${ }^{4}$. As

${ }^{1}$ KKE in specific social sectors (e.g. labor, student, women etc.) tries to create frontal organizations under its control and guidance, while it avoids cooperation with other political forces on the grounds of political purity.

${ }^{2}$ We read in the political resolution of SYRIZA's first Congress (12 July 2013): "SYRIZA is acting in line with social movement and popular claims in order to fully contribute in the development of a massive multifaceted social movement repelling governmental attack [...] forming at the same time the preconditions of a huge social and political overthrow. Government of the Left will come as a result of this huge popular mobilization and initiative".

${ }^{3}$ In the beginning of Indignados protests, Alexis Tsipras in his speech in a meeting of SYRIZA's central political committee (28 May 2011) described in detail the party's strategy in respect with popular reactions: "Dynamics of massive social resistance made its presence felt and this is important. Apparently, we cannot turn our back to all these people in an elitist and sectarian way. The logic, according to which whatever we do not control is mistaken and suspected, is totally wrong. It's not our logic. And apparently, it is neither possible nor in line with our perception for the mass movements any patronizing of these people [...]. We must participate into these struggles. In order to support and strengthen them; to tell our opinion and listen to others' opinions; to contribute to the mass processes underway; to be part of this multifaceted social movement, with our contribution, but with respect to its rules and plurality; and to contact with masses through our ideas, proposals and militantism, but always with respect to the roles and principles of this movement".

${ }^{4}$ As the authors indicate «SYRIZA has a very open alliance strategy to its left and to its right. On the one hand, it has established strong ties with social justice groups (DIKTYO), it connects to radical trade unions, and has embraced the Indignados LPEs. On the other hand, it has participated in the administration of GSEE/ADEDY and, mainly, has attracted many defected PASOK MPs and rank and file social-democrats forming the electoral front of SYRIZA/EKM just before the elections of 2012». 
seen in the Figure 2 (Papanikolopoulos et al, 2014) ${ }^{5}$, where all movement forces are set according to their political stance (left-right) and their tendency to coalesce or not, SYRIZA is placed in the leftist-cooperative quadrate. This in-between position and closeness to the mass of struggling labor forces made SYRIZA more likely to represent anti-austerity forces or, to put it another way, made the latter more likely to be coopted and integrated into the program of SYRIZA. Rudig and Karyotis link rise of the support for SYRIZA in the double elections of 2012 partly due to «their ability to attract opponents of the austerity policy who are not necessarily radicalized in terms of ideology» (Rudig and Karyotis, 2014:509).

Figure 2: Position of organizations in the political spectrum in respect with two axes, left-right and cooperative-non cooperative

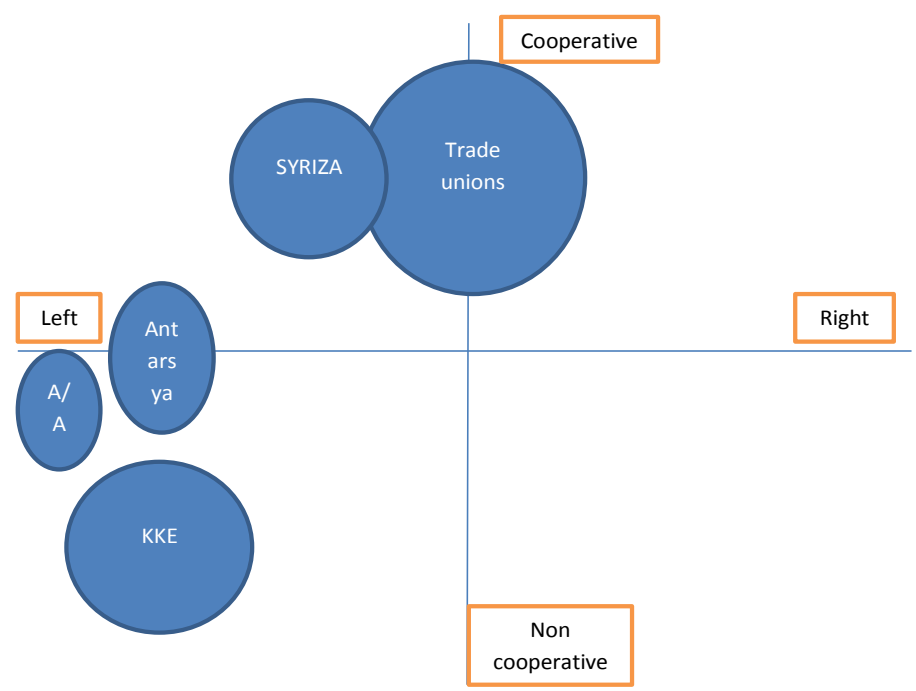

Papanikolopoulos et al, 2014

In other words, the anti-memorandum multitude «adopted» SYRIZA (Douzinas,2014). This adoption, in our opinion, became clear through a series of instances:

- During one of the first anti-memorandum big protest events (March 4, 2010) SYRIZA's MPs appeared in front of the Parliament holding a big banner and many protesters were applauding them.

${ }^{5}$ Their research locus is the existence or absence of links between organizations/groups. It is based on hundreds questionnaires distributed to core members of 34 organizations/groups participating in the antiausterity campaign and in-depth interviews with one representative from each organization/group. Research questions concern firstly the political positioning and ideology and secondly the collaboration with other organizations/groups and more particularly whether they share resources or information, do joint actions, have personal relationships or dual membership, feel solidarity with, and so on. Figure 2 depicts the position of the main political networks participating in the anti-austerity campaign according to their members' responses.

December 2019, vol. 45 
- Groups of employees in the public sector (employees in the Hellenic Broadcasting Corporation - ERT, school guards, cleaners of Ministry of Finance), after they got fired by the pro-memorandum governments, started to participate in SYRIZA's political gatherings holding banners with their claims.

- In the last anti-memorandum big demonstrations before the elections of January 25, 2015, many employees chose to thicken SYRIZA's blocs instead of marching along with their unions' leaders. As a result, SYRIZA's blocs were more numerous and denser than ever before.

Insofar the anti-austerity campaign failed to reverse austerity policy and was led to a deadlock. Every new austerity package was legislated by the parliament despite the huge popular reactions. Consequently, significant parts of the hard-hit population showed their discontent turning to the electoral arena and supporting anti-establishment parties and especially SYRIZA (Papanikolopoulos 2015a; Serdedakis and Koufidi, forthcoming). Spain and some Latin American countries witnessed similar phenomena (Oikonomakis, 2017). We call this strategy «logic of assignment», as movement activists conceptualize it. Oikonomakis (2017) argues that even the latter abandoned prefigurative politics in order to participate in the electoral process. Based on unofficial interviews and contacts, we can remark that even an important part of the people that recognize themselves as part of the antiauthoritarian/anarchist movement, who traditionally are against elections, voted for SYRIZA in 2012 double elections and/or January 2015. Why? Is this another aspect of the «logic of assignment»? We could hardly assign this kind of thinking to activists that promote «Do It Yourself» logic in practice.

However, this decision can be seen as a by-product of the unresolved tension between antithetical claims, autonomy and hegemony. This kind of tension was obvious in the movement of the squares in Greece and Spain (Prentoulis and Thomassen, 2014). The conjunction between horizontalism and representation seemed so difficult for the heterogeneous anti-memorandum multitude that support for anti-memorandum parties came by itself (Souzas and Iliopoulos, 2015:8). In this context, political outsourcing appears to protect autonomy from the concerns of hegemony rather than sacrifice prefigurative politics to institutional ones.

Similarly, SYRIZA adopted anti-memorandum protesters.

- It supported almost every social local protest (against privatization of Piraeus port, privatization of Public Water Utilities of Thessaloniki, new gold mines in Chalkidiki, or in favor of the occupation of a closed factory in VIOME) and Tsipras visited protesting communities.

- It offered legitimization to the activists of «We don't owe, we don't pay» campaign (2011), calling citizens not to pay «the unjust property tax» called ENFIA and participating 
actively in opening toll barriers in highways still under construction but already under exploitation.

- Tsipras visited ERT during its occupation by its fired employees (June 2013), while he gave a speech in Syntagma Square trying to compose the unprecedented and «undemocratic» closure of ERT, the social and movement reactions to it, and the need for governmental change via new elections, in a coherent narrative.

- Many activists entered SYRIZA's ballots in the 2012, 2014 and 2015 elections and some of them got elected: a) Konstantina Kouneva, cleaner and unionist, who was attacked with vitriol in December 22, 2008, b) Anneta Kavvadia and Aglaia Kyritsi, journalists of ERT, fired by ND-PASOK government, c) Katrougalos and Douzinas, known thanks to the speech they gave in Syntagma Square during a special event on Direct Democracy organized by the Greek Indignados.

Apart from the political developments that facilitated SYRIZA's rise, some of SYRIZA's features can be seen as movement effects.

SYRIZA in the very beginning was formed as an umbrella organization for smaller parties, organizations and groups with active participation in the leftist movement. More particularly, during '00s Synaspismos, a post euro-communist parliamentary party, after a political «left turn» in its $4^{\text {th }}$ Congress (2004), approached grass-roots movements, while small left-wing social movement organizations decided to join a coalition with Synaspismos. After 2004 «left turn» Synaspismos decided to invest in its youth branch development. Thence, Synaspismos Youth participated in every major protest (e.g. organization of European Social Forum in Athens, student mobilization of 2006-2007, December 2008 riots, hunger strike of 300 immigrants on 2011) supporting them with all kinds of resources. Its relative autonomy from the party allowed it to have its own agenda, which most of the time was more radical than the one of Synaspismos.

As for SYRIZA's program, it «was the outcome of both experience from social struggles and experience and expertise acquired within the institutions of social and political representation» (Spourdalakis, 2013:110). Additionally, many party members with double partisanship introduce systematically movement issues in the party's agenda, while during the pre-election periods progressive activists are called to contribute to party's program. In 2012 and 2015 elections, in contrary with the mainstream governmental parties, SYRIZA organized open rallies just about everywhere using «the know-how and the techniques of political mobilization acquired in its involvement in the social movements» (ibid:114).

SYRIZA's description as a «mass connective party» (ibid:103) relies upon its ambition to connect social initiatives and movement activities with similar goals and provides some 
evidence that, in majoritarian democracies, the transformation of existing parties by social movements is easier than the rise of new parties coming out of social movements.

\section{ELECTORAL SUCCESS AS A MOVEMENT EFFECT MEANS "POPULISM"?}

By assuming that both party's features and the massive political mobilization led to the rise of SYRIZA does not mean that we approach this phenomenon as a typical case of populism. Kriesi and Pappas (2015:11-12) argue that Great Recession provides an opportunity for both right-wing and the left-wing populism, expecting left-wing populism to get its chance especially in the countries hardest hit by the crisis like Greece. Their definition of populism includes «the existence of two homogeneous groups - 'the people' and 'the elite', the antagonistic relationship between the two, the idea of popular sovereignty, and a 'Manichean outlook' that opposes the positive valorization of 'the people' combined with the denigration of 'the elite» (ibid:7).

This definition -as most of definitions of populism- seems to us problematic for at least three reasons. First, we cannot easily imagine how an organized political force can make democratic politics without addressing the only legitimizing authority of the democratic era (and area), the people, and without trying to define the optimum boundary between «us» and «them». As Jasper suggests «demonization of enemies and adulation of fellows are common activities in political conflict of all sorts, generating an emotional energy important for retaining recruits to a movement. This kind of polarization seems a natural cognitive and emotional process [...] of the kind that cognitive psychology is good at grasping» (Jasper, 2004:241). In democratic states that power derives from the people, claiming for power means trying to represent people vis a vis power holders. In contrast, once in office parties ask for «consensus». It seems that adversary framing serves political challengers, while consensual framing serves whoever defends status quo. Second, the elite frequently adopts the Manichean schema of «people-elite» pretending that it is the real representative of people's interest, while the populist opposition is a kind of political, ideological or economic elite, which tries to take advantage of people's discontent. Anti-populism is in fact elite's populism. Third, the idea that an explanation of crisis based on the unwillingness and incapability of political and economic elites to deal with crisis on behalf of the middle and the lower classes is a priori incorrect makes it difficult for us to distinct populism's definition from elite's framing. It is obvious that both the economic and political crisis have causes leading us some way to the role of the elite(s), national or international. That's why it is misleading to speak about «populist communication style» which puts an emphasis on the fundamental role of the people and claims that the people have been betrayed by those in charge (Kriesi and Pappas, 2015). 
Characterizing everyone who blames the elite and/or supports a social majority's unified interest as «populist» is serving a reactionary rhetoric rather than science. As Stavrakakis and Katsambekis stress, at the same time that we witness «the proliferation of new types of 'anti-populist' discourses aiming at the discursive policing and the political marginalization of emerging protest movements against the politics of austerity, especially in countries such as Greece, Spain and Portugal», in the academia «it has [...] become commonplace to study populism and extremism together». (Stavrakakis and Katsabekis, 2014:134).

Regarding populism as ideological and political strategy, we could note that apart from «the notion of people as sovereign» (that is a core notion of western constitutions, if not of Modernity itself), SYRIZA didn't share the other components of a populist ideology (monolithic conception of the people, exclusion of 'others', illiberal vision of democracy) (Kriesi and Pappas, 2015). In contrary with Pantazopoulos (2013), who considers both SYRIZA's and Golden Dawn's discourse as «national-populist», Stavrakakis and Katsambekis (2014:135) distinguish the «people» of the extreme right (xenophobic, exclusionary, passive) from the 'people' of the left (plural, inclusive and active). Similarly, SYRIZA's political strategy was not based on a personalistic leader's capacity to mobilize in an unmediated way large numbers of mostly unorganized

followers (Kriesi and Pappas, 2015), because of both unwillingness and inability ${ }^{6}$. Besides, contrary to the «top down» strategy of the new right, new left relies on a «bottom up» strategy (Kriesi, 2015b). Furthermore, we disagree with some scholars (Pantazopoulos, 2013; Aslanidis 2016) who think of almost every massive contentious movement campaign as populist, especially when protesters with different ideological and political identities coalesce to fight against power holders' alliance (mainstream parties, economic elite, mass media owners etc.). This kind of «theory» does not make but offering certification to elites' anti-populist populism by presenting consensual politics as the only responsible and popular fronts as irrational mobs.

\footnotetext{
${ }^{6}$ Alexis Tsipras mentioned in a speech in loannina (21 March 2014): “We believe in movements' power, in social groups' action, in social struggles, in unitary initiatives that accelerate social developments. We do not therefore believe that we are infallible [...] or saviors [...]. But the only who can secure [political] reversal is you. And this is not going to happen by sitting on the couch". Furthermore, we read in the political resolution of SYRIZA's first Congress (12 July 2013): "a leftist government's goals cannot be met via a delegation rationale. Only the wider wave for democratic reversal which is going to bring Left in power can guarantee the path not only of government, but of the country itself".
}

December 2019, vol. 45 


\section{MOVEMENT RECESSION AS AN EFFECT OF SYRIZA'S ELECTORAL SUCCESS}

At this point we would like to respond to a couple of possible questions: a) Given that massiveness of protest events dropped substantially during the last two years before the elections of $25^{\text {th }}$ January 2015 (Papanikolopoulos, 2015a), while SYRIZA was increasing its political leverage, how we can speak about «electoral success as a movement effect»? b) SYRIZA's electoral success on 20 September 2015 was equally a movement effect?

The decrease of social movements activity from 2013 must be seen as a result of 1) exhaustion of the available citizens' resources after three years of escalating anti-austerity mobilization (2010-2012), 2) disillusionment regarding their collective capacity to prevent troika and Greek government from imposing new packages of austerity measures two of them where already legislated combined with several other austerity laws and 3) the transposition of their hopes in the electoral level, namely the logic of assignment (Papanikolopoulos, 2015a) This kind of substitutionalism can be seen as movement politics by other means. SYRIZA managed to act for years as movement's spokesperson, given that it could use easily a movement type language. Similarly, Greek Indignados «adopted» SYRIZA because it was speaking the same language and was transforming their agenda into a political program. In other words, SYRIZA's political leverage increased not despite current movement recession but by virtue of the previous intense movement activity, which made reciprocal «adoption» possible.

SYRIZA formed a coalition government after its victory on 25 January 2015 and a further movement recession appeared as an electoral effect. After long-lasting negotiations with Greece's creditors SYRIZA's government signed a new 3rd Memorandum in contrary with its promises for putting an end to the austerity policies. In such a context, it makes no sense to speak of SYRIZA's electoral victory on 20 September $2015^{7}$ as a movement effect too. However, the victory of «No» in the referendum of $5^{\text {th }}$ July $2015^{8}$, which SYRIZA's government called, and the polarization between the «No» and «Yes» camps, which was expressed by rival gatherings in the center of Athens (more than 150.000 vs more than 50.000 people), deepen further the boundary between anti-memorandum and pro-memorandum forces (mainstream parties, economic elite, mass media). The defeat of these latter in the referendum polls anticipated their defeat in the forthcoming elections. The pro - «No» popular mobilization did not give a boost to SYRIZA in the elections of

7 SYRIZA secured $35,5 \%$ of the votes and 145 parliamentary seats out of 300 and formed a governmental coalition with ANEL, which secured another 3,7\% of the votes and 10 seats in the Parliament.

${ }^{8}$ The dilemma was "Yes or No to the austerity measures proposed by our lenders". 61,3\% voted "No", while $38,7 \%$ voted "Yes". 
20 September 2015, but condemned the political representatives of «Yes» to another mandate in the opposition.

Greece, as many Latin-American countries (Almeida, 2015), witnessed a substantial decline of movement activity after left/central left parties took power. Oikonomakis (2017) proposes an explanation focusing on a supposed «carrot and stick» strategy adopted by SYRIZA toward contention. His explanation seems only partially correct. While repression levels declined immediately and conspicuously, new opportunities did not transform into intensification of collective action. Instead, the logic of assignment and invested hopes on the new government led to inaction. Some first (minor and/or symbolic) positive measures implemented by government and the ongoing negotiations with Greece's international lenders led Greek people to adopt a waiting stance. Of course, SYRIZA once in government adopted more moderate positions in a series of issues (Oikonomakis, 2017) as it is expected for a governmental party that «has to take into account various stakeholders and appeal to the median voter» (Hutter et al, forthcoming:12). After six months of harsh negotiations with Troika (IMF, ECB, EU), SYRIZA finally signed a third bailout agreement accompanied by new austerity measures.

Thence, its political programme before the September 2015 elections was reoriented towards the reduction of the most harmful impacts of the subsequent neoliberal packages and the implementation of equivalent counter-measures on behalf of the most vulnerable. In this context, Greek people gave to SYRIZA-ANEL coalition a second governmental chance in September 2015 elections. However, continuation of the austerity policy triggered new anti-austerity protests, yet without the massiveness witnessed in the first years of the crisis (2010-2012). This can be explained in four ways: 1) Once in government, SYRIZA's social movement partyism strategy came to an end, as party members withdrew from protesting against government, 2) after the signature of the third bailout agreement by a left-leaning party, «memorandum-anti-memorandum» political cleavage lost salience, 3) many people recognized that the international power structure was very unfavorable for a leftist government to promote substantial changes, 4) voters and adherents of SYRIZA were disappointed by both movement and institutional politics, especially after SYRIZA's setback vis a vis Greece's lenders.

\section{THE INTERPLAY BETWEEN SOCIAL MOVEMENTS, PARTIES, AND ELECTIONS}

The literature on the interactions between movements, parties, and electoral outcomes is growing and SYRIZA's case has much to offer in the relative debate. As Hutter et al. (forthcoming:6) notice, this research field is organized around four issues: a) parties as 
movement allies in the political process approach, b) parties and movements as key actors involved in the articulation of new social cleavages, c) agenda-setting power of protest, and d) interplay between movements and elections in the contentious politics approach. Indeed, the anti-austerity campaign created the necessary preconditions for the electoral and political rise of SYRIZA, thus the emergence of a new political boundary between proand anti- memorandum forces and a subsequent majoritarian socio-political category that could be transformed into a privileged electoral pool for SYRIZA. The position of the latter between contention and convention gave it the opportunity to function as a channel of transferring protest claims into the institutional arena. Besides, apart from being the parliamentary lawyer of protesters, SYRIZA deployed a full-scale social movement partyism strategy by providing crucial resources to the anti-austerity campaign.

As for the fourth strand already mentioned, case under examination appears even more fruitful. Mc Adam and Tarrow (2010:533-534) have specified six mechanisms that link movement actors to routine political actors in electoral campaigns. They argue that 1) movement tactics and innovations can be adopted by parties as electoral tools, 2) movements join electoral coalitions or turn into political parties, 3) movements engage in proactive mobilization in the

context of an electoral campaign, 4) movements engage in reactive electoral mobilization, 5) movements polarize internally parties triggering disputes between radicals and moderates, and 6) shifts in electoral regimes in the long term promote left-wing or right-wing mobilizations Some of these linkages are present in our case $(1,5)$, others absent $(3,4)$, while others need further elaboration (2) or rejection (6).

As already said, SYRIZA's in-between strategy was proved very effective in times of crisis of representation. It is dubious, however, whether SYRIZA could fulfill such a task without being helped by its specific traits formed throughout years in close connection with social movements (1). Similarly, splits within SYRIZA resulted from polarization between more movement-oriented fractions and more institutional ones. In 2010 the splitting group of moderates disagreed with SYRIZA's unreserved support to radical movements, while in the aftermath of the signature of the third memorandum in JulyAugust, 2015, among the splitting groups were Maoist and Trotskyist social movement organizations that had entered SYRIZA's coalition a decade ago (5). As for the proactive electoral mobilizations, we have already mentioned groups of fired civil servants participating in SYRIZA's political gatherings holding banners with their claims, as well as others choosing to thicken SYRIZA's blocs instead of marching along with their unions' leaders in the last anti-memorandum big demonstrations before the elections of January 25, 2015. However, it would be misleading to argue that anti-austerity protesters as such intervene massively in the electoral campaign in favor of SYRIZA (3). On the other, 
reactive electoral mobilizations were absent, since the electoral results were never disputed (4).

As for the second issue Mc Adam and Tarrow notice that movements can join electoral coalitions or turn into political parties themselves. Kriesi, in his turn, argues that «in majoritarian systems, instead of creating his own party, a challenger has a strong incentive to introduce his demands into the program of one of the existing parties» (Kriesi, 2015b:669). In the same line, Giugni and Lorenzini consider that «citizens who seek clear answers to the long-lasting recession may support radicalized political parties» (Giugni and Lorenzini, 2015:37). SYRIZA is not a new party formed by social movements. It is a party transformed by social movements, since many minor social movement organizations coalesced with a post euro-communist parliamentary party in order to broaden the political leverage of the Left. It is a party that «turned left» and invested in movement activity. Thus, our argumentation does not seek simply to confirm the idea that protest activity can reshape party systems. It rather underlines the possibility for the to turn to social movements, rather than come out of them. That's why SYRIZA triggered so intense discussion inside European Left and the European movements. However, stressing that both party's features and the massive political mobilization led to the spectacular rise of SYRIZA does not mean that this phenomenon can be explained in terms of «populism». In contrast, instead of a top-down process we witnessed a bottom-up one, with the antimemorandum forces «adopting» SYRIZA. The «logic of assignment» and «political outsourcing» associated with this very process constitute a distinct kind of relations between movements and parties, which underline the possibility for movement mobilization to replace party mobilization in times of crisis of representation. Movements can «adopt» parties.

Unlikely this linkage mechanism, the causal relationship between solidification of an enduring electoral regime and the conditioning of prospects for successful mobilizations (6) could hardly be accepted. Mc Adam and Tarrow in their insightful study (2010) have underlined the reinforcement of left-wing mobilizations under Democratic administration as well as the rise of rightist movements in the Republican era. In contrast, in Greece leftwing social and political forces are traditionally among the main organizers of popular mobilizations no matter who governs (Papanikolopoulos, 2015b, 2016), while right-wing mobilizations are traditionally marginal. Besides, as we indicated, increased opportunities for successful mobilization under left-wing administration

can promote the «logic of assignment» rather than increase mobilization. This assumption fits with Van Dyke's suggestion, according to which threats associated with a political opponent in power are more likely to trigger protest than opportunities linked to friendly governments (Van Dyke, 2001). 
Finally, we could add a seventh linkage mechanism in Mc Adam and Tarrow's list: movements can trigger snap elections. It is well accepted that movement pressure and especially the biggest anti-governmental demonstration (300-500.000 participants) of the post-junta era on 12 February 2012 triggered snap elections of May 2012 leading to SYRIZA's rise. This proves that protest cycles are not unilaterally influenced by electoral cycles, but they can on their turn give shape to these later.

\section{CONCLUSION}

SYRIZA's electoral successes between 2012 and 2015 triggered intense discussions in both political and academic levels. These electoral successes did not take place only due to economic crisis, Alexis Tsipras' charismatic leadership or SYRIZA's strategy and political message, or SYRIZA's particular ideological and organizational features. On the one hand, economic crisis made punishment of mainstream parties an international trait of the electoral outcomes throughout last years, but only in Greece led to such a spectacular rise of a minor leftist party. On the other hand, SYRIZA's features, strategy and message have been developed on the grounds of its movement activity. Furthermore, the external political conditions which SYRIZA seems to take advantage of were the immediate results of an intensive movement campaign. In other words, spectacular rise of SYRIZA was to an important extent a movement effect.

The anti-austerity campaign created the necessary preconditions for the electoral and political rise of SYRIZA, namely the emergence of a new political boundary between proand anti-Memorandum forces and a subsequent majoritarian socio-political category that could be transformed into a privileged electoral pool for SYRIZA. The position of this latter between contention and convention, institutional and non-institutional action, gave it the opportunity to function as a channel of transferring protest claims into the institutional arena. This in-between strategy was proved very effective in times of crisis of representation. It is dubious, however, whether SYRIZA could fulfill such a task without being helped by its specific traits formed throughout years in close connection with social movements.

Case under examination has crucial theoretical implications. SYRIZA's bottom-up strategy challenges the populism hypothesis, according to which SYRIZA's rise is due to populist mobilization. In contrast, the anti-memorandum multitude "adopted" SYRIZA via «logic of assignment». This strategy constitutes a distinct kind of relations between movements and parties, beyond the formation of parties by movements and vice versa, which underlines the possibility for movement mobilization to replace party mobilization in times of crisis of representation. Turn to electoral support for SYRIZA led to 
substantial decline of anti-austerity protest both before and after SYRIZA came to power, indicating that increased political opportunities under left-wing administration can promote the «logic of assignment» rather than increased mobilization. 


\section{BIBАIOГРАФІA}

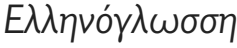

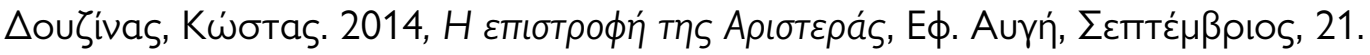

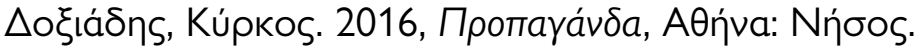

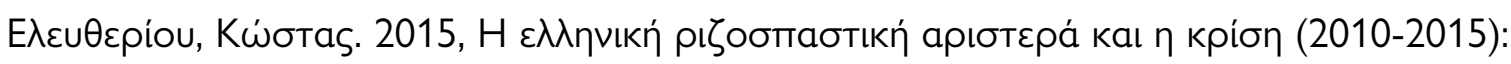

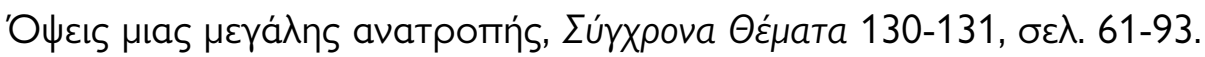

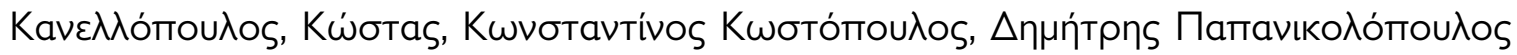

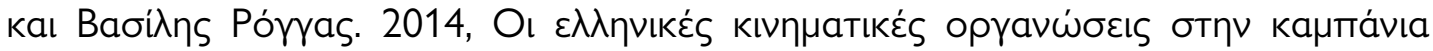

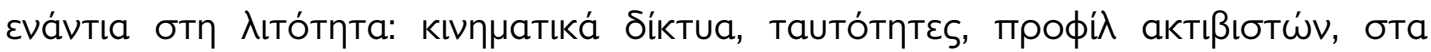

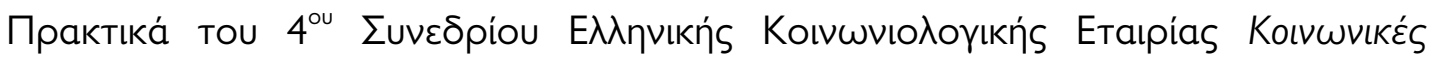

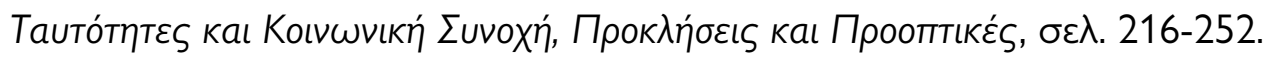

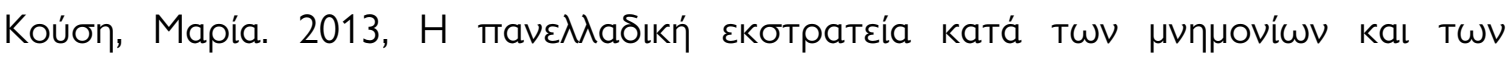

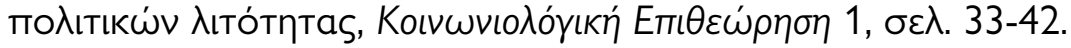

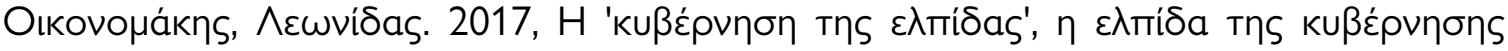

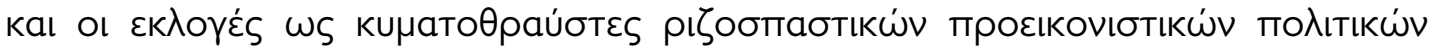

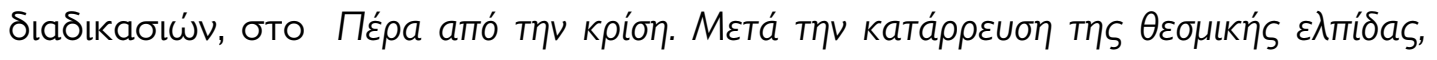

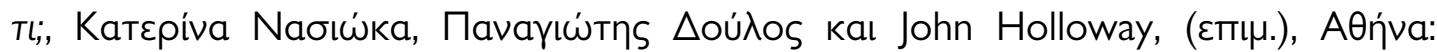

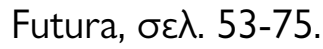

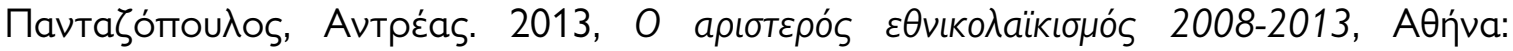
Етіккеvтро.

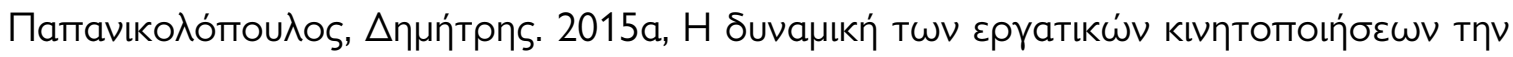

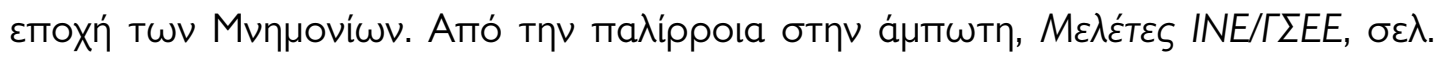
27-40.

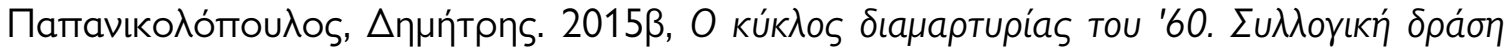

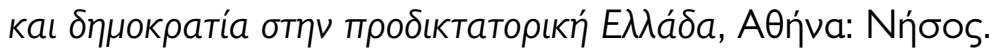

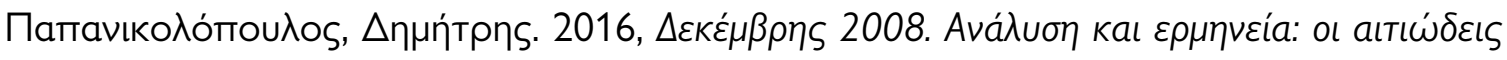

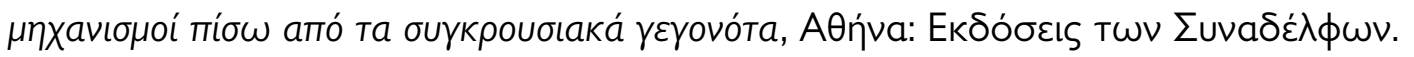

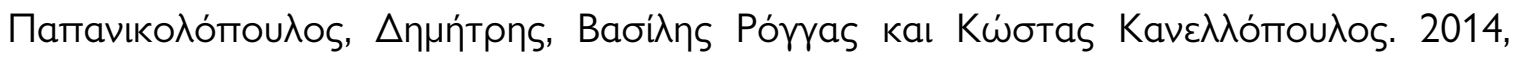

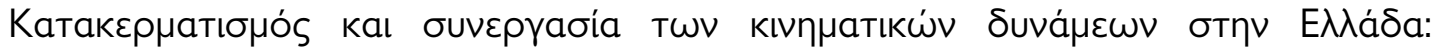

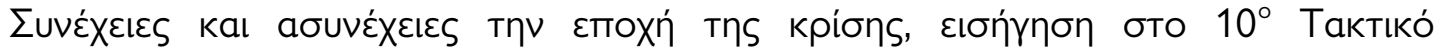

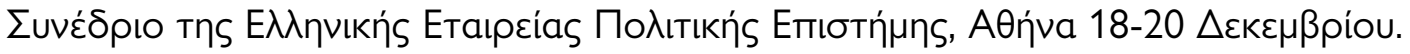

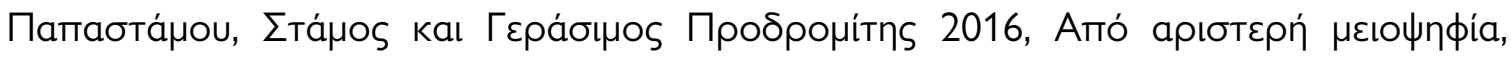

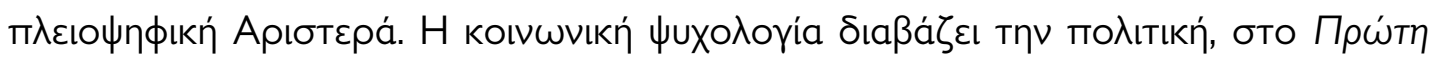

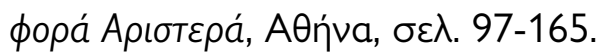




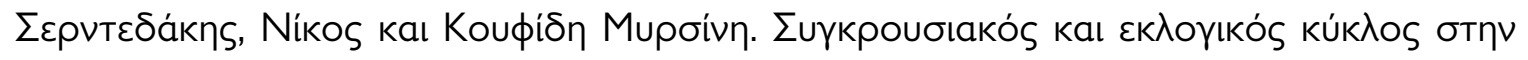

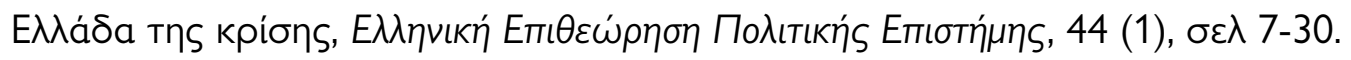

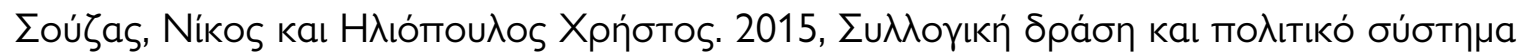

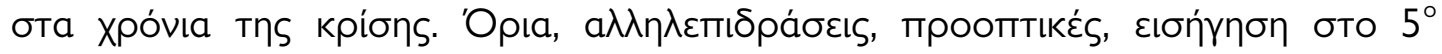

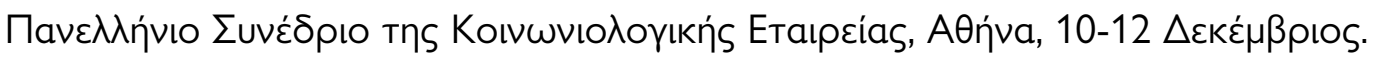

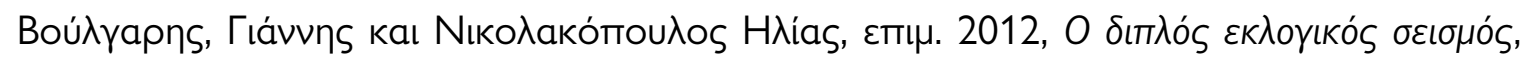

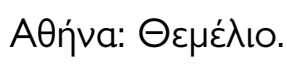

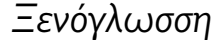

Almeida, Paul. 2010, Social Movement Partyism: Collective Action and Oppositional Political Parties, in Strategic Alliances: Coalition Building and Social Movements, Nella Van Dyke and Holly McCammon, eds. Minneapolis and London: University of Minnesota Press, pp. 169-196.

Almeida, Paul. 2015, Neoliberal forms of capital and the rise of social movement partyism in Central America, Journal of world-systems research 21(1), pp. 8-24.

Aslanidis, Paris, and Nikos Marantzidis. 2016, The Impact of the Greek Indignados on Greek Politics, Southeastern Europe 40 (2), pp. 125-157.

Aslanidis, Paris. 2016, Populist social movements of the great recession, Mobilization 21(3), pp. 301-321.

Benford, Robert, and David Snow. 2000, Framing processes and social movements: an overview and assessment, Annual Review of Sociology 26, pp. 611-39.

Castells, Manuel. 2012, Networks of hope and outrage. Social movements in the internet age, Cambridge: Politi Press, 2012.

Eleftheriou, Costas, Michalis Spourdalakis, and AthanasiosTsakiris. 2013, Greek Radical Left reactions against the crisis: Three types of political mobilization, one benefactor, Paper presented at the conference The radical left and crisis in Europe: From marginality to the mainstream? University of Edinburgh, 17 May.

Goldstone, Jack. 2003, Introduction: Bringing institutionalized and noninstitutionalized politics, in States, parties, and social movements, Jack A. Goldstone, ed. Cambridge: Cambridge University Press, pp. 1-26.

Giugni, Mario, and Jasmine Lorenzini. 2015, Citizens' reactions to economic crises in the electoral and non-electoral arenas: A research agenda, Livewhat 9(1) , pp. 1-52.

Hernandez, Enrique, and Hanspeter Kriesi. 2016, The electoral consequences of the financial and economic crisis in Europe, European Journal of Political Research 55(2), pp. 203-224. 
Hutter, Swen. 2014, Protesting Culture and Economics in Western Europe: New Cleavages in Left and Right Politics, Minneapolis: University of Minnesota Press.

Hutter, Swen, Hanspeter Kriesi, and Jasmine Lorenzini. Forthcoming, Social Movements in Interaction with Political Parties, in The Wiley Blackwell Companion to Social Movements, David A. Snow, Sarah A. Soule, Hanspeter Kriesi, and Holly McCammon, eds. Oxford: Blackwell Publishing.

Jasper, James. 2004, Intellectual Cycles of Social-Movement Research: From Psychoanalysis to Culture? in Self, social structure and beliefs: explorations in sociology, Jeffrey C. Alexander, Gary T. Marx, Christine L. Williams, eds. Berkeley \& Los Angeles: University of California Press, pp. 234-253.

Kanellopoulos Kostas, Konstantinos Kostopoulos, Dimitris Papanikolopoulos and Vassilis Rongas. 2017, Competing modes of coordination in the Greek anti-austerity campaign, 2010-2012, Social Movement Studies 16(1), pp. 101-118.

KanellopoulosKostas, Dimitris Papanikolopoulos and Angelos Loukakis. 2015, Comparing national and transnational dimensions of anti-austerity protests in the Greek debt crisis through Discursive Actor Attribution Analysis, Paper presented at the workshop Studying Social Movements against EU austerity, Roskilde University, Denmark, 7-8 May.

Karyotis, Georgios and Wolfgang Rudig. 2017, The three waves of anti-austerity protest in Greece, 2010-2015, Paper presented at the $10^{\text {th }}$ ECPR Annual Conference, Prague, 7-10 September.

Kousis, Maria and Kostas Kanellopoulos. 2014, Impacts of the Greek crisis on the contentious and conventional politics, 2012-2012, in The social impacts of the eurozone debt crisis, George Tsobanoglou and Nicholas Petropoulos, eds. Athens: Gordios Books, pp. 443-462.

Kriesi, Hanspeter, and Takis Pappas. 2015, Populism in Europe during crisis: an introduction, in European populism in the shadow of the Great Recession, Hanspeter Kriesi and Takis Pappas, eds. Colchester: ECPR-Press, pp. 1-22.

Kriesi, Hanspeter. 2015a, Political mobilization in times of crises: the relationship between economic and political crises, in Austerity and protest: popular contention in times of economic crisis, Marco Giugni and Maria T. Grasso, eds. Burlington: Ashgate, pp. 19-33.

Kriesi, Hanspeter. 2015b, Party systems, electoral systems and social movements, in The Oxford handbook of social movements, Donatella Della Porta and Mario Diani, eds. Oxford: Oxford University Press, 2015, pp. 667-680.

Kriesi, Hanspeter. 2015c, Mobilization of protest in the age of austerity, in Street politics in the age of austerity: from the Indignados to Occupy, Marcos Ancelovici, Pascale Dufour and Hélö̈se Nez, eds. Amsterdam: Amsterdam University Press, pp. 67-90. 
Krinsky, John, and Nick Crossley. 2014, Social movements and social networks: Introduction, Social Movement Studies, 13 (1), pp. 1-21.

Mair, Peter. 2011, Bini Smaghi vs. the Parties: Representative Government and Institutional Constraints, EUI Working Paper, RSCAS, http://hdl.handle.net/1814/16354

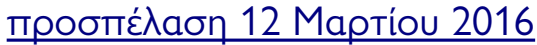

McAdam, Doug, and Sidney Tarrow.2010, Ballots and Barricades: On the Reciprocal Relationship between Elections and Social Movements, Perspectives on Politics 8(2), pp.529-542.

McAdam, Doug and Sidney Tarrow. 2013, Social Movements and Elections: Toward a Broader Understanding of the Political Context of Contention, in The Future of Social Movement Research: Dynamics, Mechanisms, and Processes, Jacquelien van Stekelenburg, Conny Roggeband, and Bert Klandermans, eds. Minneapolis: University of Minnesota Press, pp. 325-346.

McAdam, Doug, Sidney Tarrow, and Charles Tilly. 2001, Dynamics of contention, Cambridge: Cambridge University Press.

Moschonas, Gerassimos. 2013, PASOK's fall and SYRIZA's rise, Dissent 60(4), pp. 33-37.

Piven, Francis Fox, and Richard Cloward. 1977, Poor people's movements. Why they succeed, how they fail, New York: Vintage books.

Prentoulis, Marina, and Lasse Thomassen. 2014, Autonomy and hegemony in the Squares: The 2011 protests in Greece and Spain, in Radical democracy and collective movements today Alexandros Kioupkiolis and Georgios Katsambekis, eds. London: Routledge, pp.213-234.

Psimitis, Michael. 2011, The protest cycle of spring 2010 in Greece, Social movement studies 10(2), pp. 191-197.

Rudig, Wolfgang, and Georgios Karyotis. 2014, Who protests in Greece? Mass opposition to austerity, British Journal of Political Science 44(3), pp. 487-513.

Simiti, Marilena. 2014, Rage and protest: The case of the Greek Indignant movement, Hellenic Observatory. Papers on Greece and Southeast Europe (82), pp.1-36.

Snow, David, E. Burke Rochford, Jr., Steven K. Worden and Robert D. Benford. 1986, Frame alignement processes, Micromobilization, and Movement participation, American Sociological Review 51(4), pp. 464-481.

Sommer, Moritz, Jochen Roose, Franziska Scholl and Dimitris Papanikolopoulos. 2016, The Eurozone Crisis and Party Conflicts in Greece and Germany. Discursive Struggles about Responsibility, in Europe's Crisis: The Conflict-Theoretic Perspective, Tim Krieger, Bernhatd Neumärker and Diana Panke, eds. Baden-Baden: Nomos, pp. 87-110. 
Spourdalakis, Michalis. 2013, Left strategy in the Greek cauldron: Explaining SYRIZA's success, in Socialist Register 2013: The question of strategy, Leo Panitch, Greg Albo and VivekChibber, eds. London: Merlin Press, pp. 98-120.

Spourdalakis, Michalis. 2014, The miraculous rise of the 'phenomenon SYRIZA, International critical thought 4 (3), pp: 354-66.

Stavrakakis, Yannis, and George Katsambekis. 2014, Left-wing populism in the European periphery: the case of SYRIZA, Journal of Political Ideologies 19(2), pp. 119-142.

Tsakatika Myrto and Costas Eleftheriou. 2013, The Radical Left's Turn towards Civil Society in Greece: One Strategy, Two Paths, South European Society and Politics 18 (1), pp. 81-99.

Van Dyke, Nella. 2001, Protest cycles and party politics: The effects of elite allies and antagonists on student protest in the United States, 1930-1990, in States, parties, and social movements, Jack A. Goldstone, ed. New York: Cambridge University Press, pp. 226-245.

Vogiatzoglou, Marcos. 2017, Turbulent flow: Anti-austerity mobilization in Greece, inLate neoliberalism and its discontents in the economic crisis, Donatella Della Porta, Massimiliano Andretta, Tiago Fernandes, Francis O'Connor,Eduardo Romanos, Markos Vogiatzoglou, Cham: Springer, pp. 99-129 